\title{
Penerapan Speeded-Up Robust Feature pada Random Forest Untuk Klasifikasi Motif Songket Palembang
}

\author{
http://dx.doi.org/10.28932/jutisi.v5i3.1978
}

\author{
Yohannes ${ }^{\bowtie}$, Siska Devella ${ }^{\# 2}$, Ade Hendri Pandrean ${ }^{\# 3}$ \\ ${ }^{\#}$ Tekmik Informatika, STMIK Global Informatika MDP \\ Jl. Rajawali No. 14 Palembang \\ ${ }^{1}$ yohannesmasterous@mdp.ac.id \\ ${ }^{2}$ siskadevella@mdp.ac.id \\ 3adehendripandrean@gmail.com
}

\begin{abstract}
Songket is a historical heritage in the city of Palembang. Where Songket has many different types and motifs. Besides having historical value, Palembang's original Songket has high quality and complexity in the manufacturing process. As known Palembang Songket has a lot of motives, one of the ways to recognize Palembang Songket is through its motives, so that research was conducted for the classification of Palembang Songket motifs. The method used to extract features is the Speeded-Up Robust Feature (SURF), while the classification method is Random Forest. The process of forming the SURF feature is divided into two stages. The first stage is Interest Point Detection, which consists of Integral Images, Hessian Matrix Based Interest Points, Scale Space Representation and Interest Point Localization. The second stage of Interest Point Description consists of Orientation Assignment and Descriptor Based on Sum Haar Wavelet Responses. The resulting feature is used for the Random Forest classification. This study used 345 images of Palembang Songket motifs, among others, Bunga Cina, Cantik Manis, and Pulir. The images taken are based on 5 colors from each Palembang Songket motif. There are 300 images used as training data and 45 images as testing data. The test result of

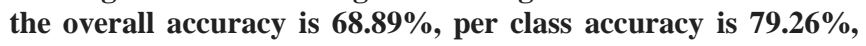
precision is 69.27 , and recall is $68.89 \%$.
\end{abstract}

Keywords- Songket Palembang; Speeded-Up Robust Feature; Random Forest.

\section{Pendahuluan}

Songket merupakan warisan sejarah yang ada di kota Palembang. Dimana kain Songket memiliki banyak ragam jenis dan motif yang berbeda. Selain memiliki nilai sejarah, Songket asli Palembang memiliki suatu tingkat kerumitan yang tinggi dalam proses pembuatannya. Songket memiliki macam bahan tenunan yang dikenal di Indonesia dan memiliki ciri khas penenunan dan motif yang berbeda antara daerah yang satu denganlainnya. Salah satu daerah yang mewarisi seni kain tenunan tradisional adalah daerah Sumatera yang dikenal dengan nama Songket yang dapat diketahui para pakar terdahulu mengenali songket pada masa kerajaan Sriwijaya. Songket sendiri telah diketahui oleh banyak masyarakat Sumatera Selatan bahwa Songket sudah mulai dipakai pada masa abad ke Sembilan Masehi di pusat kota Palembang. Banyak ragam cara untuk dapat mengetahui perbedaan dari motif songket Palembang dengan melihat motif yang terbentuk dari variasi intensitas warna sehingga dapat dipandang sebagai tekstur berwarna dari kain tenun [1]. Pada penelitian yang dilakukan oleh [2], yang berhasil melakukan pengenalan motif Songket Palembang menggunakan metode Jaringan Syaraf Tiruan dan algoritma Backpropagation dengan hasil yang baik.

Klasifikasi citra batik besurek juga sudah dilakukan oleh (Dita Retnowati, Ernawati, Kurnia Anggraini, 2018), yang membahas mengenai suatu cara untuk menentukan ciri khas jenis batik untuk membedakan dari jenis-jenis lainnya. Klasifikasi citra batik besurek berdasarkan ekstraksi fitur tekstur menggunakan Jaringan Syraraf Tiruan Self Organizing Map (SOM) [3]. Klasifikasi motif citra batik juga dilakukan oleh M. Nur Fuad dan Nanik Suciati, Klasifikasi Multilable motif citra baik menggunakan Bossted Random FERNS. Pengklasifikasian motif lebih berfokus dalam satu jenis motif batik pada satu citra yang menghasilkan akurasi 55 sampi 62 data diklasifikasi dengan benar dari data citra testing yang diujikan [4].

Deteksi gempa berdasarkan data twitter dengan menggunakan Decision Tree, Random Forest dan SVM dilakukan oleh Rendra Dwi Lingga P., yang membedakan suatu cara antara tweet yang mengandung informasi gempa sesungguhnya atau bukan dan menghasilkan akurasi recall dari metode Random Forest sebesar 96,7\% [5].

Selain itu, klasifikasi sinyal EMG pada otot tungkai selama berjalan menggunakan Random Forest yang dilakukan oleh Darma Setiawan Putra, yang didapat dari 
data biometric diperoleh hasil fitur akurasi 88,88\%, dan akurasi pengklasifikasian $72,22 \%$ [6].

Analisis pengenalan motif batik pekalongan menggunakan algoritma Backpropagation juga dilakukan oleh Vera Pebrianasari karena masyarakat awam sulit mengenali pola motif batik terus mengalami perkembangan dari segi motif dengan hasil motif batik Kawung Buketan $88,07 \%$, motif batik Burung Phoenix $87,32 \%$, motif batik Enchim 85,68 \%, motif batik Jawa Hokokai 90,73, dan motif batik Jlamprang 91,31\% [7].

Tidak hanya itu, metode CNN dan GLCM juga bisa melakukan deteksi motif batik yang hasil akhirnya dapat menghasilkan tingkat akurasi dan recall yang baik. Seperti penelitian yang telah dilakukan oleh Christian Sri Kusuma Aditya dan Mamluatul Hani'ah yang membahas satu fitur ekstraksi memungkinkan fitur vektor yang mirip dengan dua gambar berbeda dan diperlukan suatu cara yang mampu menyajikan lebih banyak karakteristik gambar batik [8]. Evaluasi pengenalan motif Songket Palembang menggunakan fitur SIFT dan SURF juga telah dilakukan dan menunjukkan perbandingan kinerja ekstraksi yang lebih baik dan akurasi yang tinggi [9].

\section{LANDASAN TEORI}

\section{A. Songket}

Songket merupakan warisan sejarah yang ada di kota Palembang. Dimana kain Songket memiliki banyak ragam jenis dan motif yang berbeda. Selain memiliki nilai sejarah, Songket asli Palembang memiliki suatu tingkat kerumitan yang tinggi dalam proses pembuatannya. Songket memiliki macam bahan tenunan yang dikenal di Indonesia dan memiliki ciri khas penenunan dan motif yang berbeda antara daerah yang satu dengan lainnya. Salah satu daerah yang mewarisi seni kain tenunan tradisional adalah daerah Sumatera yang dikenal dengan nama Songket yang dapat diketahui para pakar terdahulu mengenali songket pada masa kerajaan Sriwijaya. Songket sendiri telah diketahui oleh banyak masyarakat Sumatera Selatan bahwa Songket sudah mulai di pakai pada masa abad ke Sembilan Masehi di pusat kota Palembang. Banyak ragam cara untuk dapat mengetahui perbedaan dari motif songket Palembang dengan melihat motif yang terbentuk dari variasi intensitas warna sehingga dapat dipandang sebagai tekstur berwarna dari kain tenun [1].

\section{B. Speeded-Up Robust Feature (SURF)}

SURFadalah local feature detector dan local feature descriptor yang terinspirasi dari SIFT. SURF pertama kali diperkenalkan oleh Herbert Bay pada tahun 2006 di European Conference on Computer Vision. Algoritma SURF didasarkan pada prinsip dan langkah-langkah yang sama dengan SIFT, namun detail setiap langkahnya berbeda [10]. SURF terdiri dari dua langkah yaitu Interest Point Detection dan Interest Point Description.

Interest Point Detection yang digunakan adalah Harris Corner detector diusulkan pada tahun 1988. Berbasis pada eigen value dari matrix kedua. Namun Harris Corner bukan skala invarian tapi mengurangi konsep pemilihan skala otomatis, ini dapat mendeteksi image point dalam suatu gambar masing-masing dengan skala karakteristik. Harris Detector menggunakan determinant dari matrix hessian serta laplacian untuk mendeteksi struktur seperti blob. Interest Point Detection digunakan untuk memilih poin yang mengandung banyak informasi dan juga stabil terhadap noise dalam citra. Langkah Interest point Detection terdiri dari tahapan antara lain:

1. Integral Images.

Integral Images memberikan perhitungan cepat untuk convolution filters seperti kotak dengan jumlah semua pixels dalam gambar masukan $I$ di daerah persegi panjang yang dibentuk titik asal dan $\mathrm{x}$ menggunakan Persamaan (1).

$$
I \sum(x)=\sum_{i=0}^{i \leq x} \sum_{j=0}^{j \leq y} I(i, j)
$$

Setelah integral images dihitung, dibutuhkan tiga tambahan untuk menghitung jumlah intensitas di atas area tegak lurus dan persegi panjang dapat dilihat pada Gambar 1.

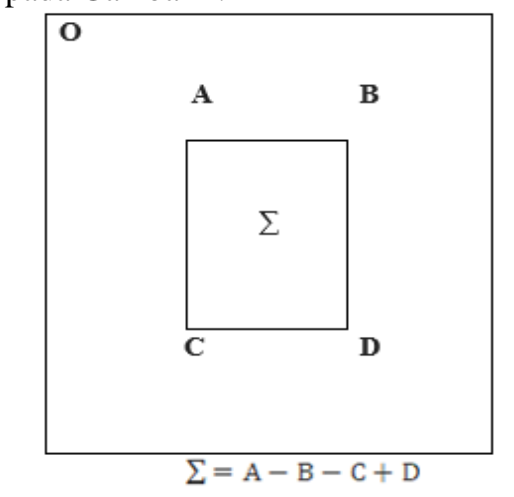

Gambar 1. Integral Images Persegi Panjang [10]

2. Hessian Matrix Based Interest Points.

Detectorpada Matrix Hessian memiliki kinerja yang baik dalam akurasi untuk mendeteksi struktur seperti gumpalan pada determinant maximum. Hessian Matrix pada skala $\sigma$ didefinisikan sebagai persamaan (2).

$$
\mathrm{H}(\mathrm{x}, \sigma)=\begin{array}{ll}
\operatorname{Lxx}(\mathrm{x}, \sigma) & \operatorname{Lxy}(\mathrm{x}, \sigma) \\
\operatorname{Lxy}(\mathrm{x}, \sigma) & \operatorname{Lyy}(\mathrm{x}, \sigma)
\end{array}
$$

Detektor tetap berkinerja baik, dan penurunan kinerja tidak melebihi performa dari konvolusi cepat yang dibawa oleh discretisation dan 
cropping. Karena filter nyata tidak lebih jauh dengan filter kotak untuk Matrix Hessian terlihat pada Gambar 2. Ini perkiraan turunan Gaussian orde kedua dan dapat dievaluasi dengan computation cost yang sangat rendah menggunakan integral image. Oleh karena itu waktu perhitungan tidak tergantung pada ukuran filter.
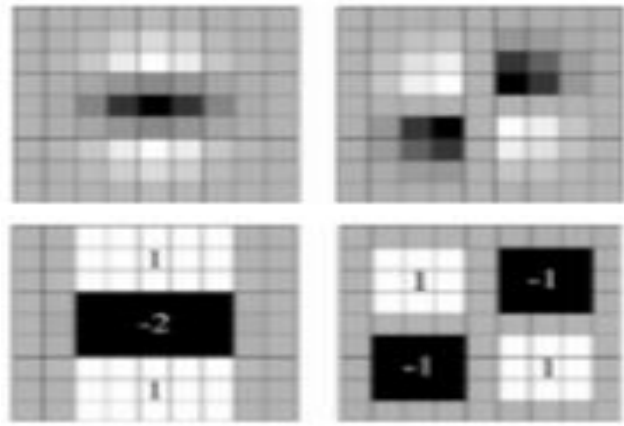

Gambar 2. Gaussian Orde Kedua [10]

\section{Scale Space Representation}

Interest point perlu ditemukan pada skala yang berbeda karena pencarian korespondensi sering membutuhkan perbandingan dalam gambar dimana akan terlihat pada skala yang berbeda. Gambar berulang kali dihaluskan dengan Gaussian kemudian diberi sampel untuk mencapai tingkat lebih tinggi agar gambar mendapatkan gambar dimana tepian dan gumpalan dapat ditemukan.

Ruang skala dibagi menjadi oktaf. Satu oktaf mewakili serangkaian filter yang diperoleh dengan menggabungkan gambar input yang sama dengan ukuran filter yang semakin besar. Secara total, satu oktaf mencakup faktor penskalaan dua kali lipat. Kemudian oktaf kedua akan terjadi penambahan ukuran filter, setelah itu diikuti oktaf ketiga dan keempat. Oleh karena itu, ruang skala akan dianalisis dengan meningkatkan skala ukuran filter daripada mengurangi ukuran gambar, dapat dilihat pada Gambar 3.
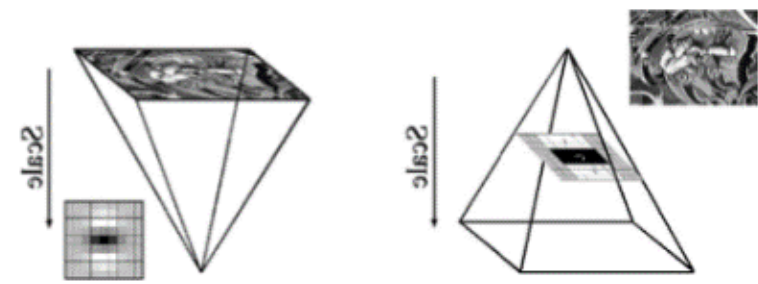

Gambar 3. Integral Images Skala Filter [10]

\section{Interest Point Localization}

Interest point kembali ke corner detection, dimana fitur sudut yang terdeteksi sebagai tujuan utama untuk memperoleh fitur gambar yang kuat, stabil dan terdefinisi dengan baik. Namun sebagian besar corner detector tidak khusus untuk sudut, tetapi untuk daerah gambar lokal yang memiliki variasi tingkat tinggi di segala arah. Untuk melokalisasi interest point pada gambar dan skala berlebih akan digunakan varian cepat dari matriks hessian. Skala ruang interpolasi sangat penting dalam mendeteksi poin dengan menggunakan detector. Berikut gambar yang menunjukkan fitur interest point dapat dilihat Gambar 4.

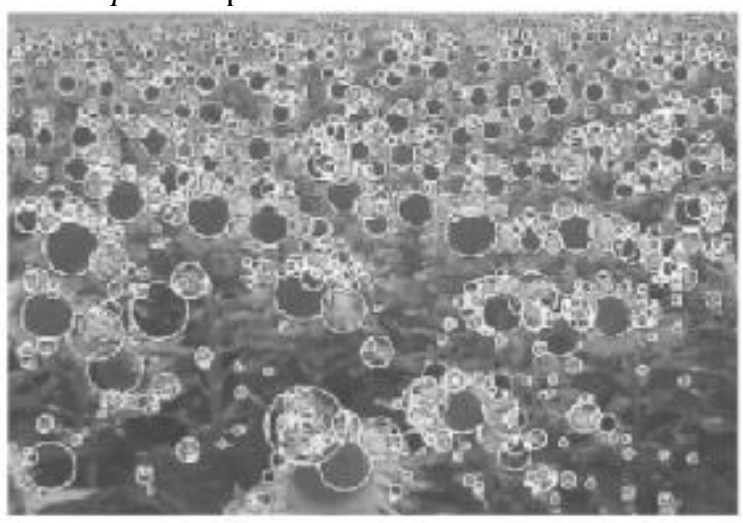

Gambar 4. Hessian Based Detectors [10]

Interest point description berbagai macam deskriptor fitur yang lebih baik telah diusulkan pada deskriptor yang mewakili distribusi fitur skala kecil dalam lingkungan interest point. Dapat dijelaskan bahwa descriptor akan menangkap sejumlah besar key point pada pola spatial intensity. SIFT dapat menghitung histogram dari gradien berorientasi lokal di sekitar interest point dan menyimpan dalam bentuk vektor orientasi untuk masing-masing lokasi penyimpanan. Langkah deteksi didasarkan pada perbedaan rata-rata tanpa interpolation pada langkah deskripsi pada histogram integral. Dengan menggunakan matrix hessian dapat lebih cepat untuk meningkatkan pencocokan. Langkah interest point description terdiri dari tahapan sebagai berikut:

a. Orientation Assignment.

Agar rotasi gambar tidak berubah akan dilakukan identifikasi orientasi yang dapat direproduksi untuk interest point, untuk dapat menghitung respons wavelet haar dalam arah $\mathrm{x}$ dan y dalam lingkaran jari-jari di sekitar interest point dengan skala di mana interest point akan terdeteksi. Langkah pengambilan sampel bergantung pada skala yang dipilih. Ukuran wavelet Haar bergantung pada skala dan panjang sisi agar dapat menggunakan integral images untuk penyaringan yang lebih cepat.

Setelah respons wavelet dihitung dan ditimbang dengan Gaussian yang berpusat pada interest point, respons tersebut direpresentasikan sebagai pointpoint dalam ruang dengan kekuatan respon horizontal dan kekuatan respons vertikal di 
sepanjang ordinat. Respon horizontal dan vertikal dalam window akan dijumlahkan kemudian menghasilkan vektor orientasi lokal. Vektor yang terpanjang pada semua window menentukan orientasi interest point. Penggunakan SURF untuk deteksi objek dapat ditemukan lebih cepat untuk dihitung dan dapat meningkatkan kekhasan. Haar Wavelet Filters dapat dilihat pada Gambar 5.
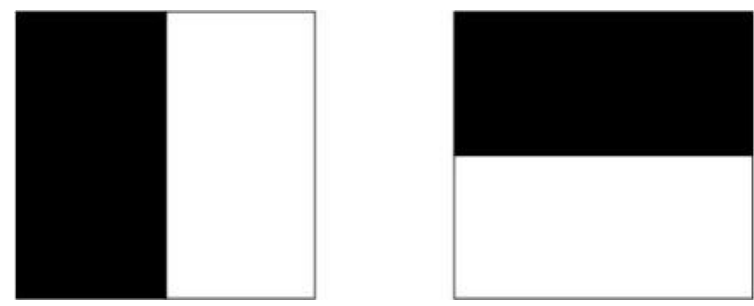

Gambar 5. Haar Wavelet Filters [10]

b. Description based on sum of Haar wavelet responses.

Untuk ekstraksi deskriptor, langkah pertama terdiri dari membangun wilayah persegi yang berpusat di sekitar interest point dan berorientasi sepanjang orientasi yang dipilih pada bagian sebelumnya. Wilayah tersebut dibagi secara teratur menjadi lebih kecil. Untuk setiap sub-wilayah akan dihitung Haar wavelet response pada titik sampel yang berjarak secara teratur. Untuk singkatnya akan dipanggil $d x$ Haar wavelet response dalam arah horizontal dan mewarnai Haar wavelet response dalam arah vertikal dapat dlihat kembali pada Gambar 5. Horizontal dan vertikal ditentukan sehubungan dengan orientasi interest point yang dipilih dapat dilihat pada Gambar 6.

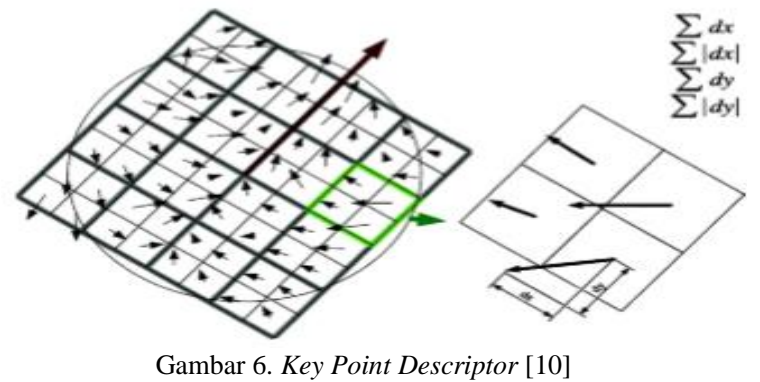

\section{Random Forest (RF)}

Metode random forest merupakan metode yang dapat meningkatkan hasil akurasi, karena dalam membangkitkan simpul anak untuk setiap node dilakukan secara acak. Metode ini digunakan untuk membangun pohon keputasan yang terdiri dari root node, internal node dan leaf node dengan mengambil atribut dan data secara acak sesuai ketentuan yang berlaku. Root node merupakan simpul yang terletak paling atas atau biasa disebut sebagai akar dari pohon keputusan. Internal node adalah simpul percabangan, dimana node ini memiliki output minimal dua dan hanya ada satu input. Sedangkan leaf node atau terminal node merupakan simpul terakhir yang hanya memilki satu input dan tidak memiliki output. Pohon keputusan dimulai dengan cara menghitung nilai entropy sebagai penentu tingkat ketidakmurnian atribut dan nilai information gain [11]. Untuk menghitung nilai entropy digunakan rumus seperti pada persaman berikut:

Entropy $(\mathrm{Y})=-\Sigma_{i} p(c \mid Y) \log _{2} p(c \mid Y)$

Dimana:

Y : Himpunan kasus

$\mathrm{p}(\mathrm{c} \mid \mathrm{Y}) \quad$ : Proporsi nilai Y terhadap kelas c.

$(Y, a)=$ Entropy $(\mathrm{Y})-$

$\Sigma_{v \in} \operatorname{Values}(a) \frac{\left|Y_{v}\right|}{\left|Y_{a}\right|}$ Entropy $\left(Y_{v}\right)$

Dimana:

Values(a) : Semua nilai yang mungkin dalam himpunan kasus a

$\mathrm{Y}_{\mathrm{v}} \quad$ : Subkelas dari $\mathrm{Y}$ dengan kelas $\mathrm{v}$ yang berhubungan dengan kelas a

$\mathrm{Y}_{\mathrm{a}} \quad$ : semua nilai yang sesuai dengan a

Random Forest memodifikasi langsung dari metode bagging yang memaksa keragaman antara pengklasifikasi dasar dalam ensemble method. Bagging di ambil dari sampel dataset training dengan beberapa kali penggantian training dari sekelompok pengklasifikasi dasar. Pengklasifikasi memberikan suara untuk grup gabungan dari pengklasifikasi dasar. Untuk meningkatkan akurasi prediksi classifier, bagging lebih memfokuskan pada akurasi base individual classifiers. Untuk bagging faktor yang diberlakukan keragaman dalam ensemble classifier adalah pengambilan sampel acak dari dataset training untuk melatih setiap base classifier.

Untuk mengatasi bagging inefficiencies, dua modifikasi utama dipertimbangkan dalam pengelompokkan Random Forest. Pertama, Random Forest hanya menggunakan pohon keputusan sebagai pengklasifikasi dasar. Karena pengklasifikasi pohon keputusan biasanya tidak stabil, maka lebih baik dengan menggunakan bagging pengklasifikasi dasar. Kedua, setiap pohon keputusan dilatih dengan fitur-fitur terbaik di antara serangkaian fitur A yang dipilih secara acak di antara fitur-fitur B yang terkandung dalam vektor fitur untuk mendorong keragaman antara pengklasifikasi dasar. Perubahan kecil ini menegakkan keragaman ensemble pohon tanpa benar-benar mempengaruhi akurasi prediksi pohon 
keputusan. Random Forest dianggap sebagai model yang tepat untuk menangani sejumlah besar dataset input, ketidakseimbangan dataset, dan memberikan pendekatan empiris untuk melacak interaksi variabel [12].

\section{METODOLOGI PENELITIAN}

\section{A. Metodologi}

Metodologi yang digunakan untuk melakukan penelitian sebagai berikut. Rancangan metodologi dapat dilihat pada Gambar 7.

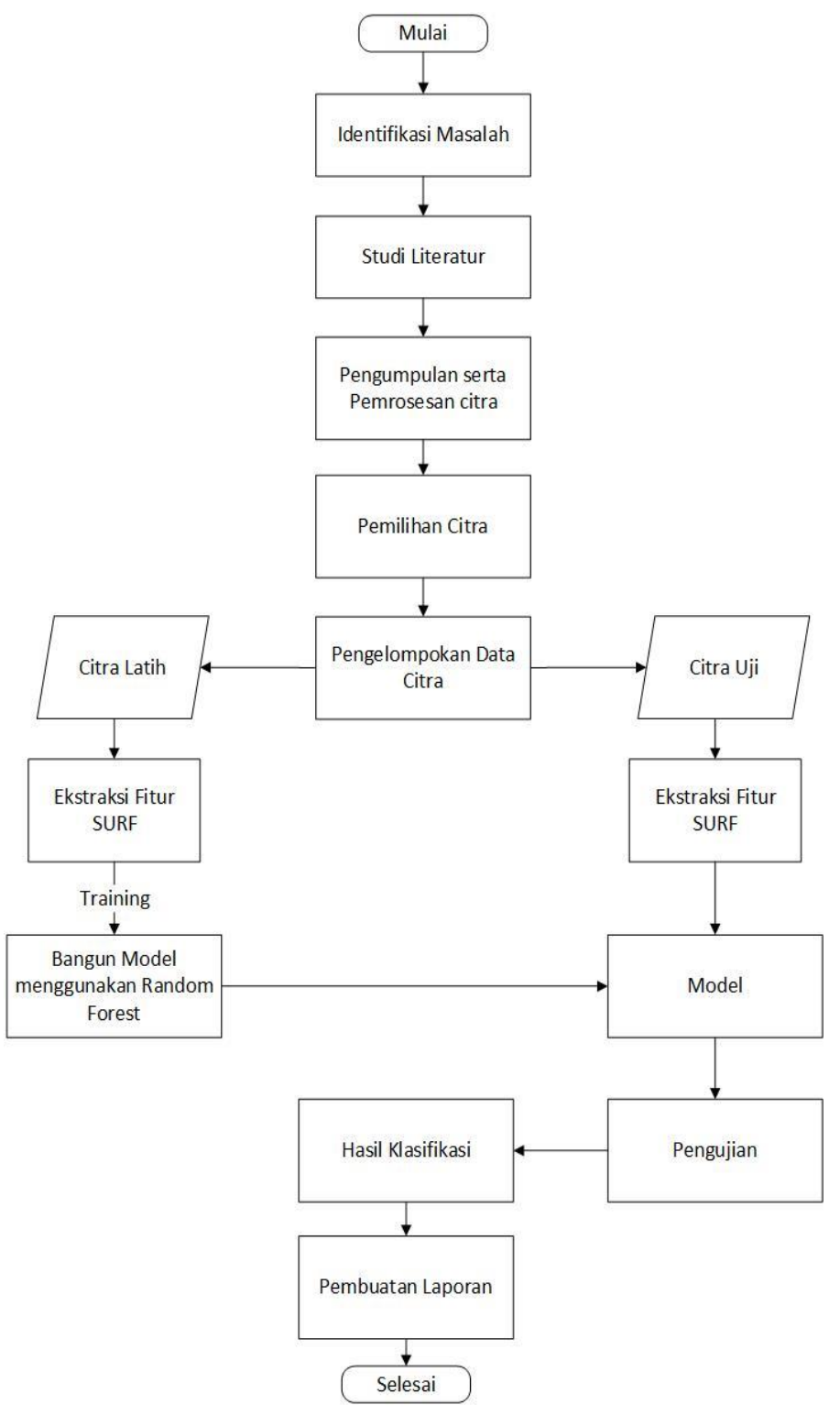

Gambar 7 Rancangan Metodologi

\section{Studi Literatur}

Tahapan ini merupakan pembelajaran mengenai topik permasalahan penelitian melalui jurnal yang dikumpulkan, yaitu jurnal yang terkait mengenai pengenalan jenis batik dan songket serta jurnal yang menggunakan metode klasifikasi Random Forest dan metode ekstraksi Speeded Up Robust Feature.

\section{Pengumpulan Data Citra}

Tahap ini merupakan proses-proses pengumpulan data berupa citra motif songket Palembang. Adapun tahapan dalam mengumpulkannya, yaitu pemotretan citra dan pengumpulan data citra, pemotongan citra dan pengelompokan data untuk citra latih dan citra uji. Tahapan-tahapan tersebut dapat dilihat pada Gambar 8.

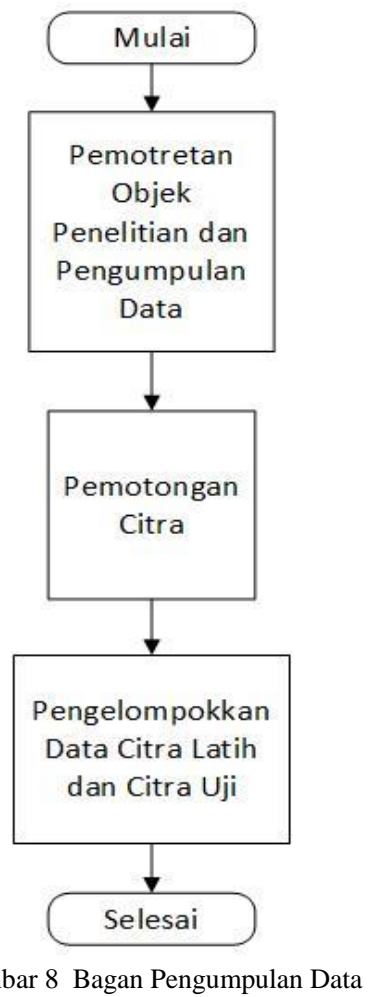

A. Pemotretan Objek Penelitian dan Hasil Pemotretan

Tahapan ini merupakan proses saat melakukan pengambilan gambar objek penelitian dapat dilihat pada Gambar 9. Kamera yang digunakan untuk pemotretan citra adalah kamera SLR Nikon D5000. 


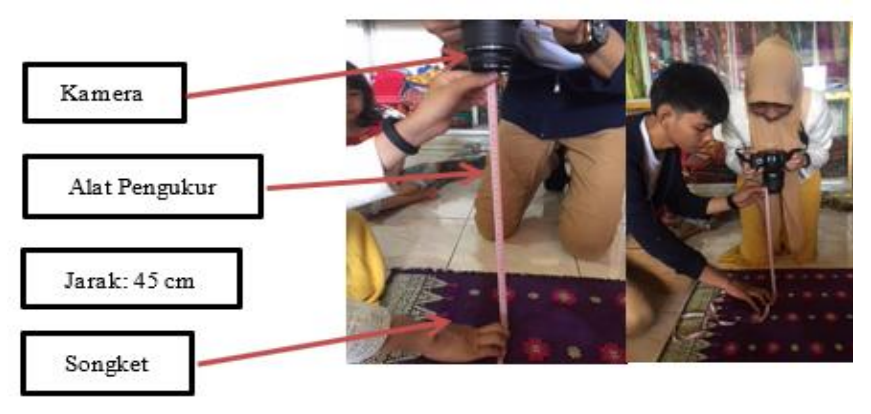

. Gambar 9 Pengambilan Gambar Objek

Ukuran gambar yang didapat yaitu 2048 x 4096 pixels, kemudian didapat hasil pengumpulan data berdasarkan motif-motifnya dapat dilihat pada Gambar 10.

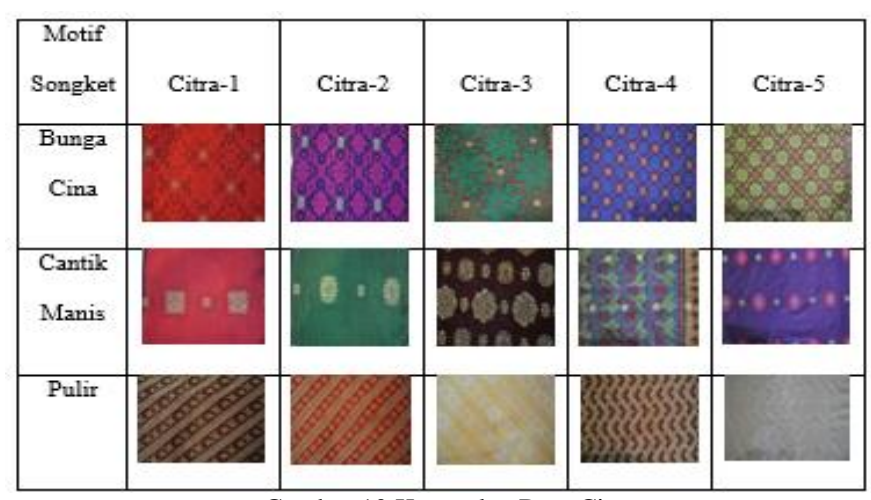

Gambar 10 Kumpulan Data Citra

\section{B. Pemotongan Citra}

Tahapan ini merupakan proses untuk cropping citra motif songket sehingga pada saat pemrosesan data citra dapat dilakukan dengan efisien. Ukuran citra asli yang berukuran 2048 x 4096 pixel kemudian di cropping menjadi 256 × 256 pixel. Data citra yang telah diubah ukurannya tersebut digunakan sebagai data uji. Berikut merupakan bagan proses dari pemotongan citra dapat dilihat pada Gambar 11 .

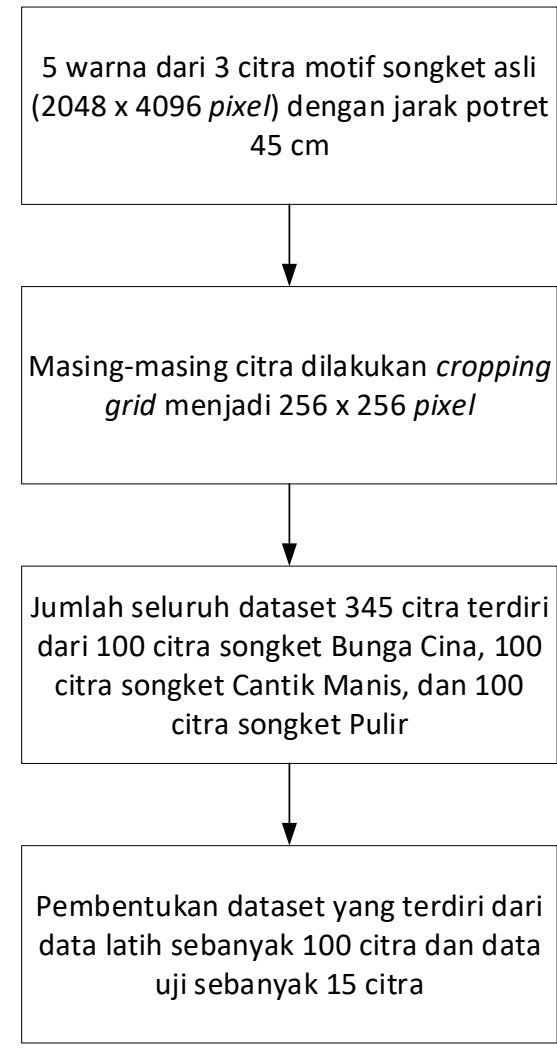

Gambar 11 Bagan Proses Pemotongan Citra

3. Pengelompokan Data Citra

Setelah citra motif songket didapatkan dan telah melalui proses cropping, semua cropping citra akan digabung sesuai dengan masing-masing motif. Seluruh jumlah dataset dari 3 motif berjumlah 345 citra. Masing-masing motif memiliki 115 citra. Lalu pembagian data akan dikelompokkan menjadi citra latih berjumlah $70 \%$ dan citra uji berjumlah $30 \%$ dari satu motif songket dan didapatkan citra latih 100 gambar dan citra uji 45 gambar.

4. Ekstraksi Fitur SURF

Setelah ukuran citra seragam, kemudian akan dilakukan ekstraksi fitur citra menggunakan fitur SURF untuk mendapatkan key point dari citra untuk masuk ke data latih. Flowchart SURF dapat dilihat pada Gambar 12. 


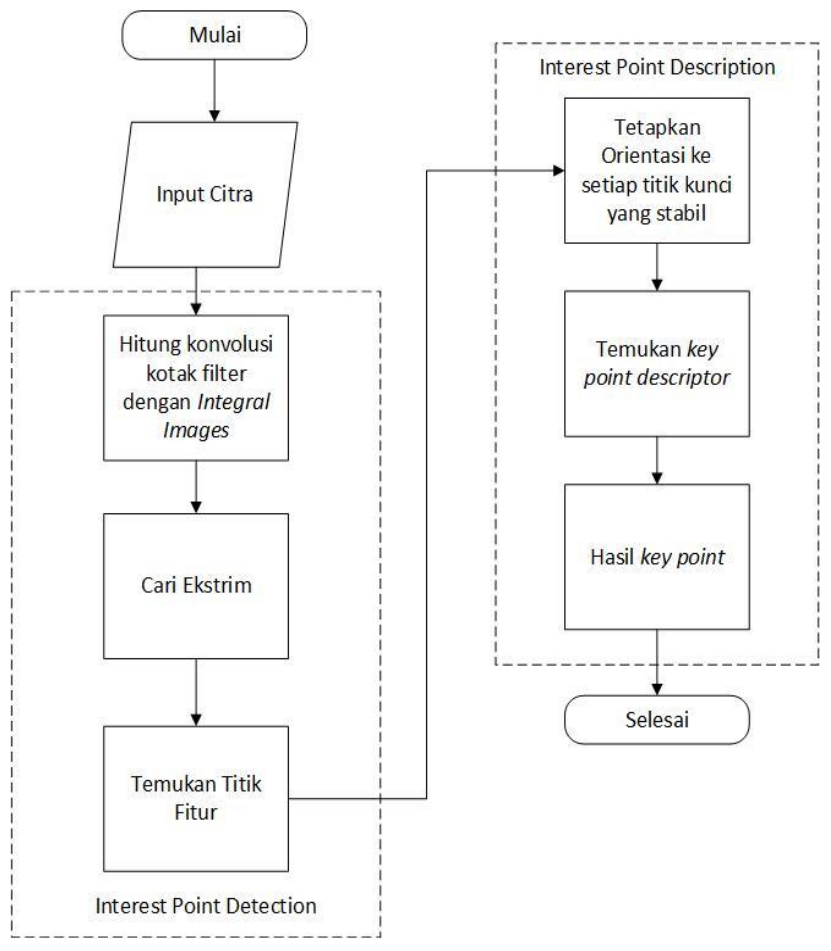

Gambar 12 Flowchart SURF

5. Model Klasifikasi Random Forest

Tahap ini merupakan proses mengklasifikasi citra motif songket dengan menggunakan metode klasifikasi Random Forest. Pembentukan model setelah dilakukan ekstraksi fitur SURF dapat dilihat pada Gambar 13 dan klasifikasi menggunakan Random Forest dapat dilihat pada Gambar 14.

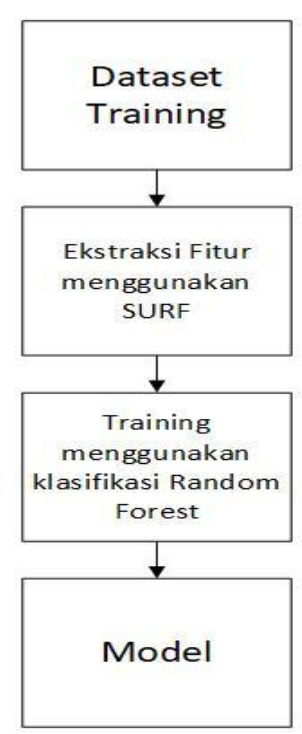

Gambar 13 Pembentukan Model

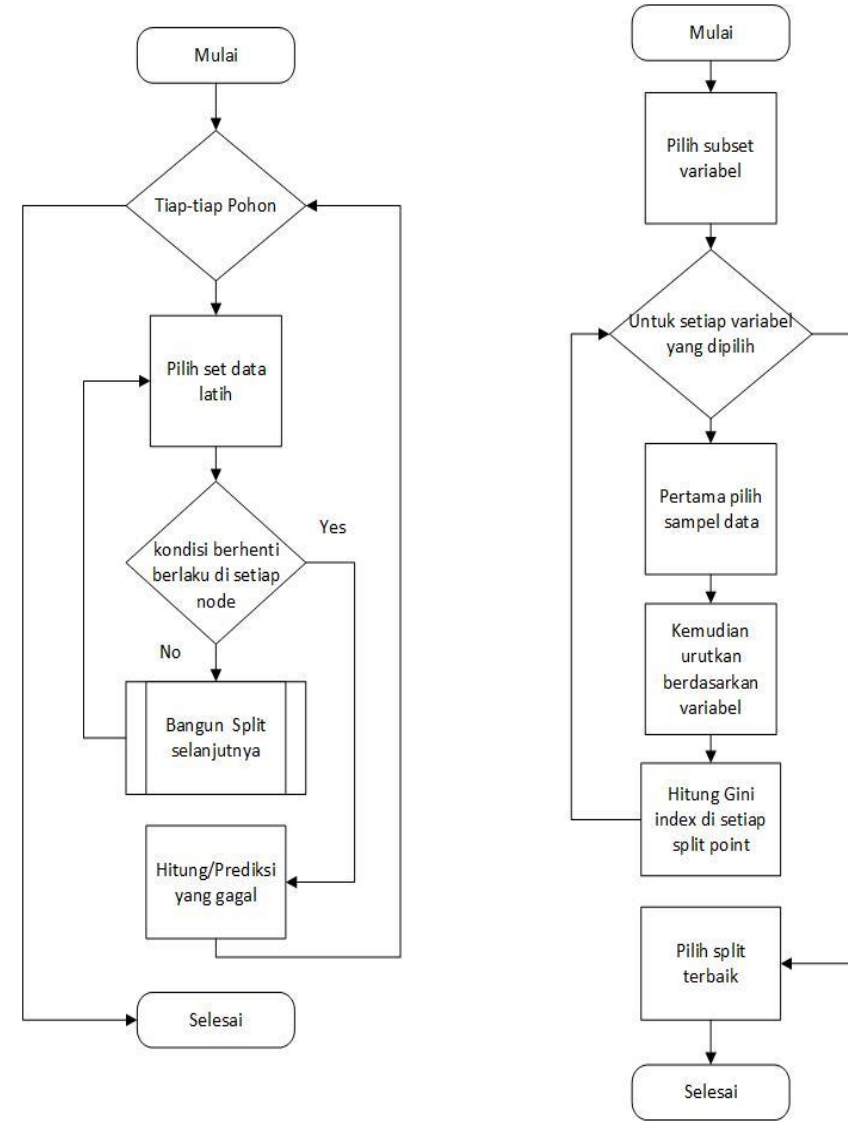

Gambar 14 Flowchart Random Forest

6. Hasil

Hasil klasifikasi dari pengujian motif songket Palembang dapat diukur menggunakan accuracy, precision, dan recall.

$$
\begin{aligned}
& \text { Accuracy overall }=\frac{\Sigma \text { Data Uji Benar }}{\Sigma \text { Total } U j i} \times 100 \% \\
& \text { Accuracy perclass }=\frac{T P+T N}{T P+T N+F P+F N} \times 100 \% \\
& \text { Precision }=\frac{T P}{T P+F P} \times 100 \% \\
& \text { Recall }=\frac{T P}{F N+T P} \times 100 \%
\end{aligned}
$$

\section{Keterangan:}

TP : Jumlah data positif citra yang terklasifikasi dengan benar oleh sistem.

TN: Jumlah data negatif citra yang terklasifikasi dengan benar oleh sistem

FP: Jumlah data positif citra yang terklasifikasi salah oleh sistem

FN: Jumlah data negatif citra yang terklasifikasi salah oleh sistem 
7. Analisis Hasil

Melakukan proses analisis hasil pada penelitian yang telah dilakukan mengenai pengenalan motif songket Palembang menggunakan metode klasifikasi Random Forest dan metode ekstraksi Speeded-Up Robust Feature.

\section{PENGUJIAN DAN PEMBAHASAN}

A. Implementasi Ekstraksi SURF

Pada tahap ini, dilakukan proses ekstraksi SURF terhadap setiap data citra training dan testing. Setiap data citra training dan testing yang telah melalui proses ekstraksi akan memperoleh bentuk keypoint descriptor data train dan data testing, bentuk keypoint descriptor dapat dilihat pada Gambar 15, 16,17, dan 18.

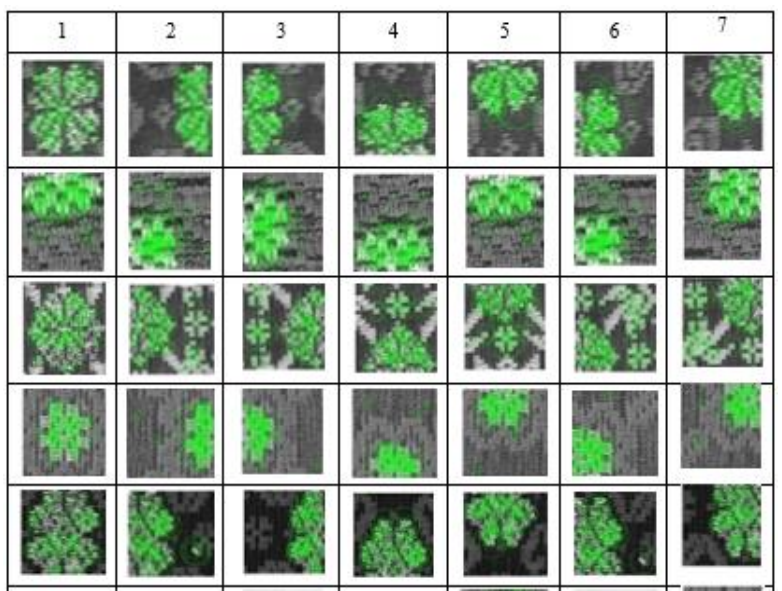

Gambar 15 Keypoint Descriptor Bunga Cina data Train

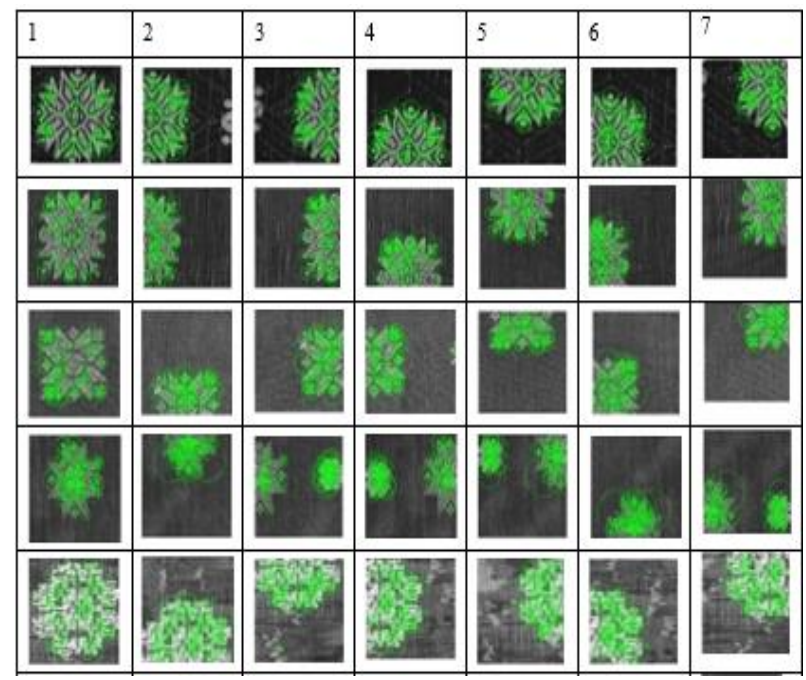

Gambar 16 Keypoint Descriptor Cantik Manis data Train

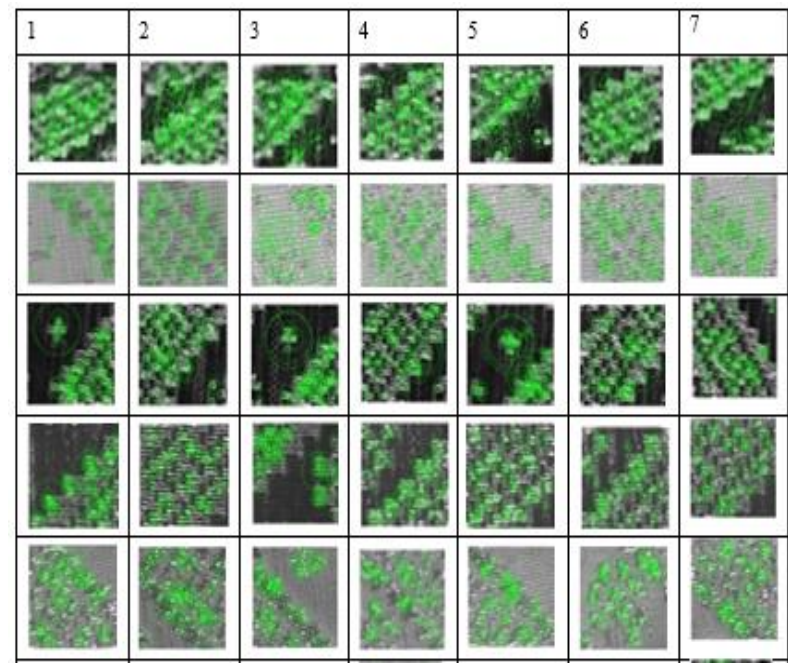

Gambar 17 Keypoint Descriptor Pulir data Train

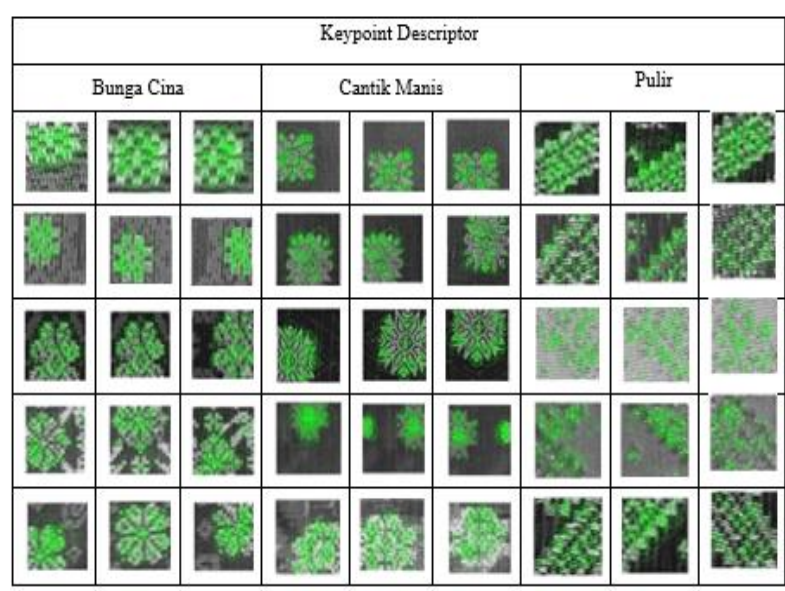

Gambar 18 Keypoint Descriptor Pulir data Train

B. Implementasi Klasifikasi Random Forest

Tahap ini merupakan tahapan dalam menerapkan metode klasifikasi Random Forest untuk mendapatkan classifier yang terbentuk pohon kemudian pada masing-masing pohon memiliki class yang paling populer. Bentuk pohon yang dihasilkan Random Forest untuk mendapatkan prediksi testing dapat dilihat pada Gambar 16: Random Forest mampu mengenali bentuk karakteristik dari motif songket Cantik Manis lebih baik dibandingkan dengan Bunga Cina, dan Pulir, karena pohon keputusan yang dihasilkan menunjukkan bahwa Cantik Manis memiliki 10 leaf, Bunga Cina memiliki 8 leaf dan Pulir memiliki 13 leaf. Leaf pada pohon keputusan menyatakan sebuah solusi. Dengan demikian dapat disimpulkan bahwa Pulir memiliki solusi terbaik dibandingkan dengan Bunga Cina dan Cantik Manis.

\section{Confusion Matrix}

Tahapan ini merupakan tahapan confussion matrix untuk mendapatkan hasil prediksi kelas melalui klasifikasi Random Forest berdasarkan classifier yang sesuai antara nilai 
keypoint descriptor data Train dan nilai keypoint descriptor data Testing. Sehingga dapat diketahui hasil confussion matrix-nya pada Gambar 17.

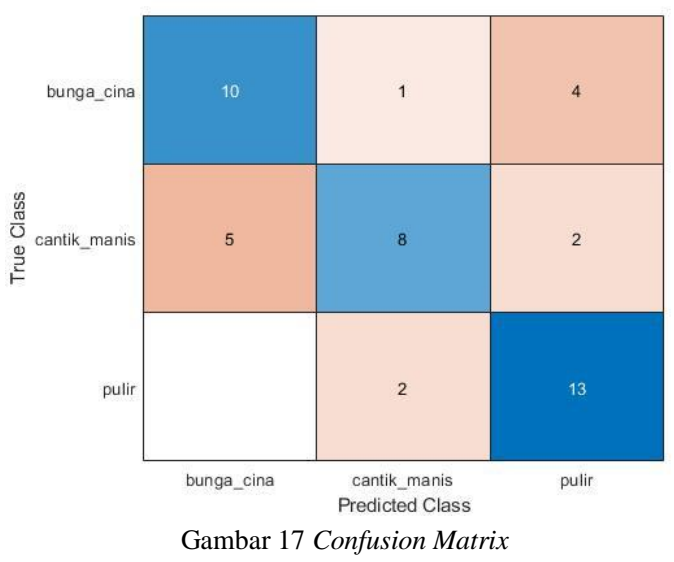

Hasil Confusion Matrix menunjukkan bahwa hasil yang didapat dengan menggunakan metode klasifikasi Random Forest untuk motif songket Bunga Cina dapat dikenali sebanyak 10, untuk motif songket Cantik Manis dapat dikenali sebanyak 8 dan untuk motif songket Pulir dapat terklasifikasi sebanyak 13.

\section{Hasil Klasifikasi}

Dari Gambar 17, dapat diketahui bahwa hasil tingkat pengenalan terbanyak dari jumlah total data testing yang diperoleh dalam pengujian menggunakan model Random Forest yaitu Cantik Manis. Evaluasi hasil pengujian klasifikasi motif songket Palembang dapat dilihat pada Tabel I untuk Overall Accuracy, Tabel II untuk Per Class Accuracy, Tabel III untuk Precision dan Tabel IV untuk Recall dan Gambar 18 adalah grafik perbandingan hasil klasifikasi.

\section{GRAFIK PERBANDINGAN HASIL KLASIFIKASI}

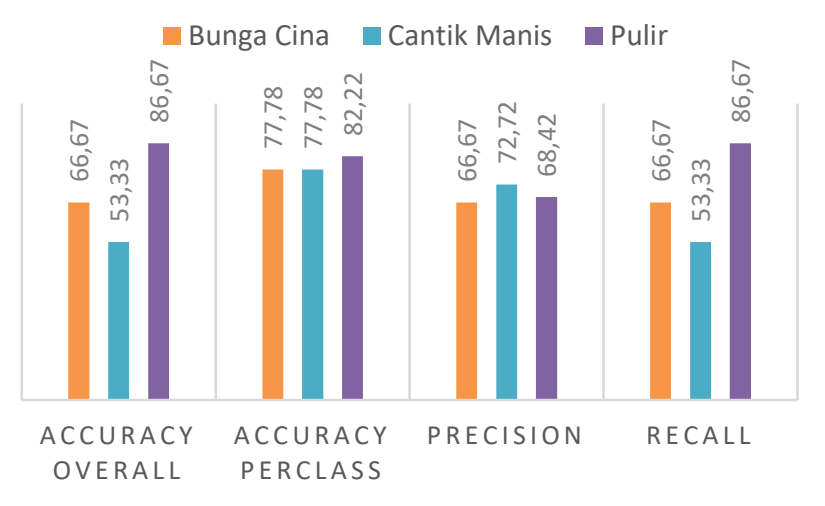

Gambar 18 Grafik Perbandingan Hasil Klasifikasi
TABEL I

OVERALL ACCURACY

\begin{tabular}{|l|c|c|c|}
\hline Motif & $\begin{array}{c}\text { Data Uji Benar } \\
\text { Klasifikasi }\end{array}$ & $\begin{array}{c}\text { Jumlah } \\
\text { Total Uji }\end{array}$ & $\begin{array}{c}\text { Overall Accuracy } \\
(\%)\end{array}$ \\
\hline $\begin{array}{l}\text { Bunga } \\
\text { Cina }\end{array}$ & 10 & 15 & $66,67 \%$ \\
\hline $\begin{array}{l}\text { Cantik } \\
\text { Manis }\end{array}$ & 8 & 15 & $53,33 \%$ \\
\hline Pulir & 13 & 15 & $86,67 \%$ \\
\hline
\end{tabular}

TABEL II

PER CLASS ACCURACY

\begin{tabular}{|l|c|c|c|c|c|}
\hline Motif & TP & TN & FP & FN & $\begin{array}{c}\text { Per Class } \\
\text { Accuracy (\%) }\end{array}$ \\
\hline $\begin{array}{l}\text { Bunga } \\
\text { Cina }\end{array}$ & 10 & 25 & 5 & 5 & $77,78 \%$ \\
\hline $\begin{array}{l}\text { Cantik } \\
\text { Manis }\end{array}$ & 8 & 27 & 3 & 7 & $77,78 \%$ \\
\hline Pulir & 13 & 24 & 6 & 2 & $82,22 \%$ \\
\hline
\end{tabular}

TABEL III

PRECISION

\begin{tabular}{|l|c|c|c|}
\hline Motif & TP & $\boldsymbol{F N}$ & Precision (\%) \\
\hline $\begin{array}{l}\text { Bunga } \\
\text { Cina }\end{array}$ & 10 & 5 & $66,67 \%$ \\
\hline $\begin{array}{l}\text { Cantik } \\
\text { Manis }\end{array}$ & 8 & 7 & $53,33 \%$ \\
\hline Pulir & 13 & 2 & $86,67 \%$ \\
\hline
\end{tabular}

TABEL IV

RECALL

\begin{tabular}{|l|c|c|c|}
\hline Motif & TP & FP & Recall (\%) \\
\hline $\begin{array}{l}\text { Bunga } \\
\text { Cina }\end{array}$ & 10 & 5 & $66,67 \%$ \\
\hline $\begin{array}{l}\text { Cantik } \\
\text { Manis }\end{array}$ & 8 & 3 & $72,72 \%$ \\
\hline Pulir & 13 & 6 & $68,42 \%$ \\
\hline
\end{tabular}

\section{KESIMPULAN}

Berdasarkan hasil pengujian dapat disimpulkan dari penelitian ini bahwa hasil performa metode SURF (Speeded-Up Robust Feature) dan Random Forest untuk motif songket palembang ini yaitu mampu mengenali motif songket Bunga Cina dengan Precision sebesar $66,67 \%$, untuk nilai Recall sebesar $66.67 \%$ dan Acuracynya sebesar $77,78 \%$. Motif songket Cantik Manis dengan Precision sebesar $72,72 \%$, nilai Recall sebesar 53,33\% dan Accuracynya sebesar 77,78\%. Sedangkan motif songket Pulir memiliki Precision sebesar 68,42\%, nilai Recall sebesar $86.67 \%$ dan accuracy-nya sebesar $82.22 \%$. Untuk akurasi keseluruhan (Overall Accuracy) didapat Bunga Cina sebesar $66.67 \%$, Cantik manis 53,33\% dan Pulir $86.67 \%$. 


\section{SARAN}

Berdasarkan kesimpulan tersebut, untuk menghasilkan akurasi yang lebih baik, berikut saran yang nantinya dapat bermanfaat untuk penelitian selanjutnya.

1. Dapat menggunakan modifikasi metode ekstraksi fitur SURF.

2. Memperbanyak jumlah data set training dan testing serta menambah jenis motif songket Palembang selain Bunga Cina, Cantik Manis dan Pulir.

\section{DAFTAR PUSTAKA}

[1] N. M. Setiohardjo and A. Harjoko, "Analisis Tekstur untuk Klasifikasi Motif Kain (Studi Kasus Kain Tenun Nusa Tenggara Timur)," IJCCS, vol. 8, no. 2, pp. 177-188, 2014.

[2] A. Riztyan, R. B. Dariska, Rusbandi, and Willy, "Analisis Pengenalan Motif Songket Palembang Menggunakan Algoritma Propagasi Balik," STMIK MDP, pp. 1-8, 2013.

[3] Y. Brasilka, Ernawati, and D. Andreswari, "Klasifikasi Citra Batik Besurek Menggunakan Jaringan Syaraf Tiruan Self Organizing Map (SOM)," J. Rekursif, vol. 3, no. 2, pp. 132-145, 2015.
[4] M. N. Fuad and N. Suciati, "Klasifikasi Multilabel Motif Citra Batik Menggunakan Boosted Random Ferns," J. Ilm. Teknol. Inf., vol. 16, no. 1, pp. 79-89, 2018.

[5] R. D. Lingga, C. Fatichah, and D. Purwitasari, "Deteksi Gempa Berdasarkan Data Twitter Menggunakan Decision Tree, Random Forest, dan SVM," J. Tek. ITS, vol. 6, no. 1, pp. 159-162, 2017.

[6] D. S. Putra, A. D. Wibawa, and M. H. Purnomo, "Klasifikasi Sinyal EMG pada Otot Tungkai Selama Berjalan Menggunakan Random Forest," J. Inotera, vol. 1, no. 1, pp. 51-56, 2016.

[7] V. Pebrianasari, E. Mulyanto, and E. Dolphina, "Analisis Pengenalan Motif Batik Pekalongan Menggunakan Algoritma Backpropagation," Techno.COM, vol. 14, no. 4, pp. 281-290, 2015.

[8] C. S. K. Aditya, M. Hani'ah, R. R. Bintana, and N. Suciati, "Batik Classification using Neural Network with Gray Level Co-occurence Matrix and Statistical Color Feature Extraction," Int. Conf. Information, Commun. Technol. Syst., pp. 163-168, 2015.

[9] D. Willy, A. Noviyanto, and A. M. Arymurthy, "Evaluation of SIFT and SURF Features in the Songket Recognition," ICACSIS, pp. 393 396, 2013.

[10] H. Bay, T. Tuytelaars, and L. Van Gool, "SURF: Speeded Up Robust Features," ECCV, vol. 3951, p. 14, 2006.

[11] Y. S. Nugroho and N. Emiliyawati, "Sistem Klasifikasi Variabel Tingkat Penerimaan Konsumen Terhadap Mobil Menggunakan Metode Random Forest," J. Tek. Elektro, vol. 9, no. 1, pp. 24-29, 2017.

[12] A. Dehzangi, S. Phon-Amnuaisuk, and O. Dehzangi, "Using Random Forest for Protein Fold Prediction Problem: An Empirical Study," J. Inf. Sci. Eng., pp. 1941-1956, 2010. 